
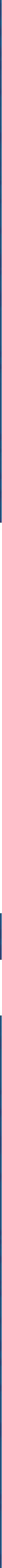


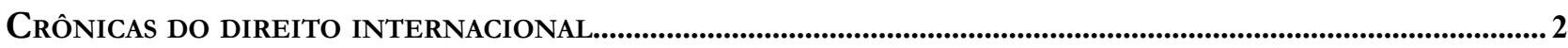

Nitish Monebhurrun

Alice Rocha da Silva

Julia Motte-Baumvol

Rafael Freitas de Oliveira

Roberta Greco

CRÔNICAS DO DIREITO INTERNACIONAL DOS INVESTIMENTOS .11

Nitish Monebhurrun

Reconhecimento E ExecuÇão de Sentenças Estrangeiras: anÁlise do projeto Em andamento na Conferência da Haia de Direito Internacional Privado

Nadia de Araujo

Fabrício Bertini Pasquot Polido

Os CASAMENTOS E AS PARCERIAS ENTRE PESSOAS DO MESMO SEXO NO DIREITO INTERNACIONAL PRIVAdO BRASILEIRO: ASPECTOS TRANSNACIONAIS DAS FAMÍLIAS CONTEMPORÂNEAS.

Bruno Rodrigues de Almeida

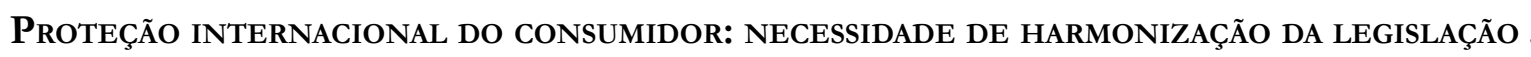
54

Héctor Valverde Santana

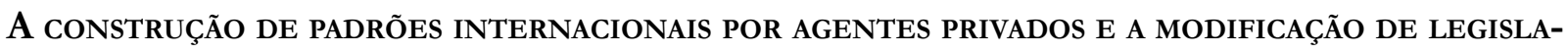
Ção NACIONAL: ALTERAÇÃo do PADRÃo DE CONTABILIDADE PARA EMPRESÁRIOS NO BRASIL.

Cleíse Nascimento Martins Costa

THE DEBATE ON COMPANIES' LIABILITY FOR INTERNATIONAL ENVIRONMENTAL DAMAGES: A COMPARISON BETWEEN THE JURISDiCTIONAL RULES OF THE EUROPEAN UNION AND THE UNITED STATES

Carina Costa de Oliveira

DesenVOlVIMENTO E APLICAÇÃo DA TEORIA dos VíNCUlOS MAIS ESTREITOS NO DIREITO INTERNACIONAL PRIVADO: POR UMA REDISCUSSÃO DO MÉTODO DE SOLUÇÃO DO CONFLITO DE LEIS 101

Jamile Bergamaschine Mata Diz

Rodrigo Vaslin Diniz

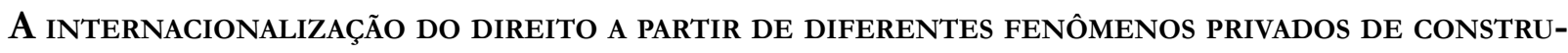
ÇÃO NORMATIVA 117

Fernando Lopes Ferraz Elias 
Leilane Serratine Grubba

Human TRAFFicking: IDENTIFYING FORCED LABOR IN MULTINATIONAL CORPORATIONS \& THE IMPLICATIONS OF LIABILITY

Tara M. Parente

Aplicação dos princípios UNIDROIT no Plano Brasil maior: o SUPRIMENTO de UMA lacuna NA POLÍTICA BRASILEIRA DE DESENVOLVIMENTO ECONÔMICO

Guilherme Freire de Melo Barros

Marcelle Franco Espíndola Barros

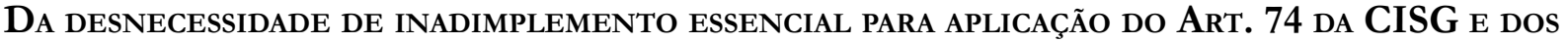
DANOS EFETIVAMENTE RECUPERÁVEIS

Renata Caroline Kroska

ESSAY ON UNEQUAL TREATIES AND MODERNITY THROUGH THE EXAMPLE OF BILATERAL INVESTMENT TREATIES

Nitish Monebhurrun

CONCEITOS DE RELAÇÕES INTERNACIONAIS E TEORIA DO DIREITO DIANTE DOS EFEITOS PLURALISTAS DA GLOBALIZAÇÃO: GOVERNANÇA GLOBAL, REGIMES JURÍDICOS, DIREITO REFLEXIVO, PLURALISMO JURÍDICO,

CORREGULAÇÃO E AUTORREGULAÇÃO . 216

Gabriela Garcia Batista Lima

\section{Outros Temas}

CONVENÇão SOBRE OS DIREITOS DAS PESSOAS COM DEFICIÊNCIA: COMO "INVISÍVEIS" CONQUISTARAM SEU ESPAÇO .230

Luana da Silva Vittorati

Matheus de Carvalho Hernandez 


\title{
The debate on companies' liability for international environmental damages: a comparison between the jurisdictional rules of the European Union and the United States ${ }^{*}$
}

\author{
O debate sobre a responsabilidade de empresas por \\ danos ambientais internacionais: uma comparação \\ entre as regras de competência jurisdicional dos \\ Estados Unidos e da União Europeia
}

Carina Costa de Oliveira**

\section{Resumo}

A reparação de danos ambientais internacionais requer a utilização de instrumentos de direito internacional público e privado. Considerando que a reparação de danos ambientais é dificilmente alcançada por meio do direito internacional público, os métodos do direito internacional privado podem ser utilizados de modo complementar. Por exemplo, as regras sobre competência jurisdicional, quando elaboradas com foco na proteção ambiental, podem contribuir para que um litígio seja julgado pelo tribunal que será substancialmente e processualmente capaz de resolver a controvérsia. Dois contextos são especificamente relevantes para a análise dessas normas de competência relacionadas à matéria ambiental: Estados Unidos e União Europeia (UE). Ns dois âmbitos estão localizadas as sedes de grandes multinacionais potencialmente causadoras de danos ambientais internacionais. Mesmo que a União Europeia seja mais atuante nas negociações internacionais ambientais que os Estados Unidos, a primeira é mais limitada juridicamente para julgar controvérsias ambientais envolvendo danos causados por empresas europeias em Estados não membros da UE. Os Estados Unidos possuem competência universal para julgar empresas americanas que tenham cometido danos em outros Estados por meio do Alien's Tort Act (ATCA). Apesar de prever esse instrumento, os últimos casos como Chevron no Equador têm demonstrado a insuficiência desse meio para garantir a reparação de danos ambientais às vítimas não americanas. Mesmo assim, os dois contextos possuem exemplos relevantes de previsões normativas ligadas às normas de competência que podem contribuir para uma melhor proteção ambiental.

Palavras chaves: Reparação de danos ambientais. Direito internacional privado. Competência jurisdicional. Responsabilidade. Competência universal. Proteção ambiental.

\section{Abstract}

* Recebido em 07.04.2014 Aceito em 17.05.2014

** Professor at Brasilia University Law Faculty. PhD Paris II- Panthéon Assas. E-mail: carina2318@yahoo.com.br
The reparation of environmental damages in international law concerns public and private international law. Because efefficient reparation of environmental damages is hardly achieved only by public international law, private international law methods can be used to fill the gaps of the former law field. For instance, the norms on jurisdictional competence, if focused on environmental protection, may contribute to choosing a tribunal which may be procedurally and substantially best 
placed to settle an environmental dispute. Two contexts are specifically relevant for this analysis: the European Union and the United States. The most representative multinationals which are potentially able to cause international environmental damages are established in these regions. Even if the European Union is more involved in the international negotiations than the United States, the former is more limited judicially to judge environmental cases concerning damages caused by European companies in States outside the European Union. The United States of America has a universal competence to judge the American companies through the Alien's Tort Act (ATCA). This being said, whether it is at the European Union's or at the United States' level, the existing legal means do not allow to reach a satisfactory reparation of the environmental damages. At that level, the law appears as being extremely incomplete. However, these two frameworks give examples of what can be accomplished to reach a better coordination of the jurisdictions in a perspective that would further aim at the environmental protection.

Keywords: Reparation of environmental damages. Private international law. Jurisdictional competence. Liability. Universal competence. Environmental protection.

\section{Introducion}

The complexity of the environmental man-made disasters ${ }^{1}$ make the perspective of effectively preventing and repairing the damages in the national, regional and international context, using the public international law, less likely. The issue of hydrocarbons spills in the Mexican gulf at the border of France and Spain, in Equator, Nigeria, and Indonesia, caused by wellknown Companies such as BP, Exxon Valdez, Shell underline the incomplete treatment of the damages reparation through the public international law, as the cases are barely brought to international courts, and the compensations are far from repairing the negative consequences for the environment that result from these damages.

The use of numerous techniques is necessary for the control of non-State actors, such as the companies that are responsible for a great part of the environmental

1 CARON, D. D.; LEBEN, C. (Éd.), Les aspects internationaux des catastrophes naturelles et industrielles. The Hague, Martinus Nijhoff Publishers, 2001; BALLARINO. Questions de droit international privé et dommages catastrophiques, R.C.A.D.I., 1990. p. 302. damages. Their capacity of relocation, economic and legal circulation in several States reduces the probability of a control over their activities. There are very few environmental conventions directly dealing with such companies. The examples that exist, like the Convention on the Damages Caused by the Hydrocarbons, concern companies in a limited way. Within the framework of this convention, only the national courts remain competent if a damage is caused by a pollution they are liable for ${ }^{2}$.

Within this framework, private international law which is a complement to public international law appears as a possible method to compensate this deficiency ${ }^{3}$. In this sense, one of the usable methods is the regulation on conflicts of jurisdiction and rules which determine the aptitude of the courts of the forum State to identify the disputes consisting of one foreign element, by the rules of international jurisdiction ${ }^{4}$. Considering that the States are free to extend or restrain the competence of their courts, the classical sense of the dispute, does not necessarily lead to a harmonious functioning of the international network of the state of jurisdiction ${ }^{5}$. In contrast, when it comes to designate the competent court to judge an international case concerning a general interest ${ }^{6}$, such as the repair of an environmental damage, the interest of regulating these relations must go beyond a designation of competence.

The international jurisdictional competence must be conducted to assure a good administration of justice ${ }^{7}$ and consequently, this must have a substantial function that enables the judge to identify if the national legislation of the forum State can exercise a normative

2 For instance, the Treaty on Principles Governing the Activities of States in the Exploration and Use of Outer Space, including the Moon and Other Celestial Bodies, entered into force on 10 October 1967, Art. VI.

3 About this topic see: OLIVEIRA, C. C. La réparation des dommages environnementaux en droit international: contribution à l'étude de la complémentarité entre le droit international public et le droit international privé. Saarbrücken: Universitaires Européennes, 2012.

4 BATIFFOL, H.; LAGARDE, P. Droit international privé, 7. éd. Paris: L.G.D.J., 1983. t. 2. p. 442; NIBOYET, M. L; LA PRADELLE, G. G. Droit international privé. Paris: LGDJ, 2007. p. 284; BUREAU, D.; MUIR-WATT, H. Droit international privé to: parte générale. Paris: PUF, 2010. t. 1. p. 137.

5 BATIFFOL, H. Aspects philosophiques du droit international privé. Paris: Dalloz, 2002.

6 USUNIER, L. La régulation de la compétence juridictionnelle en droit international privé, Paris: Economica, 2008. p. 285.

7 CJUE, EDate Advertising mbH c. Olivier Martinez, Robert Martinez c. MGN Limited, Joined cases, C-509/09 et C-161/10, 25 October 2011, para. 48; CJUE, Zuid-Chemie c / Philippo's Minerlenfabriek, C-189/08, 16 July 2009, para. 24. 
control over the settlement of the international dispute $^{8}$. The procedural questions must follow the same process. This substantial function exists among other things, within the framework of common law States and within the framework of the regional integration, like the European Union, but is unfortunately still inexistent within the international framework.

A few environmental treaties provide for rules on conflicts of jurisdiction. On the other hand, these rules do not have the substantial function to designate a court which could better repair an environmental damage. Two goals can be pointed out regarding the use of these rules: giving the priority to another court to judge the case or facilitate the coordination of the procedures of the diverse jurisdictions. As regards to the first statement, the priority becomes evident when it is given to: a) courts which would be the more appropriate to judge the case'; b) the enforcement of the treaties which are already effective ${ }^{10} ; \mathrm{c}$ ) courts which have already been seized to settle the dispute ${ }^{11} ;$ d) a court that already has the exclusive competence to decide ${ }^{12}$; d) a treaty that has rooms for forthcoming development of the rules ${ }^{13}$.

The rules on the conflicts of jurisdictions and their coordination within the regional and international framework can be efficient since the national courts better fit the judgment of the environmental damages and can be advisable to judge the case.

An example is that the victims of these international environmental damages can, within a coordination framework, file a lawsuit before the court that could be the more appropriate to analyze the proofs or to

8 USUNIER, L. La régulation de la compétence juridictionnelle en droit international privé, Paris: Economica, 2008. p. 89.

9 United Nations Convention on the Law of the Sea, Montego Bay, 10 December 1982, entered into force on the 16 November 1994, art. 282.

10 The Convention on International Trade in Endangered Species of Wild Fauna and Flora (CITES), Washington, 03 March 1973, entered into force on the $1^{\text {st }}$ July 1975, art. XIV.24; International Convention on Civil Liability for Oil Pollution Damage, 29 November 1969, entered into force on the 19 June 1975, Art. XII.

11 The Convention on conciliation and arbitration within the CSCE (Conference on Security and Co-operation in Europe, Stockholm, 15 December 1992, Art. 19.1.

12 Vienne Convention on Civil Liability for Nuclear Damage, 21 May 1963, Art. 1 e), Art. XI.1-3; International Convention on Civil Liability for Oil Pollution Damage, 29 November 1969, entered into force on the 19 June 1975, Art. IX 1-3.

13 WOLFRUM, R.; MATZ, N. Conflicts in Internationalenvironmental law. Berlin, 2003. p. 121. Example: art. 211 para. 1 UNCLOS. guarantee the more efficient procedures that could deal with the property of the counsel. This is important, considering the impossibility of the victims to file a complaint before an international court - which causes them to rely on the national courts. On the other hand, this admissibility of the victims and this coordination between the courts, within the national framework, has not yet been established. Each State uses its own rules to receive the requests made by the foreigners or to cooperate with the other courts.

At the international level, the Hague Conference has envisioned an international harmonization of the rules of the conflicts of jurisdictions centering on the civil responsibility of the environmental damages. On the other hand, no tangible document has seen the light of day so far, which is regrettable since a treaty would be an essential legal instrument guaranteeing the access to justice in the cross-border situations ${ }^{14}$. The existing document has been realized within the framework of the permanent bureau of the conference, in February of 2010, and states the importance attached to a Convention or a law regarding, firstly, the applicable law, and secondly, the competence of the court ${ }^{15}$.

Regarding the provisions within the framework of the European Union and the United States, the policies are different. Even if the European Union is more involved in the international negotiations than the United States, the former is more limited judicially to judge environmental cases concerning damages caused by European companies in States outside the European Union. The United States of America has a universal competence to judge the American companies through the Alien's Tort Act (ATCA). This system allows the victims of damages endured outside the United States and caused by American companies to sue the latter before the former's jurisdictions.

This being said, whether it is at the European Union's or at the United States' level, the existing legal means do not allow to reach a satisfactory reparation of the environmental damages. At that level, the law

14 Concerning the incidence of public international law in this context see: BUREAU, D.; MUIR-WATT, H. Droit international privé. Paris: PUR, 2010. t. 1. p. 67.

15 The Permanent Bureau of the Hague Conference on Private International Law, «Should the Hague Conference revisit the scope and nature of possible work in the field of civil liability for environmental damage?», paragraph 10. Available at: <http:// www.hcch.net/upload/wop/genaff2010pd12f.pdf>. See at the 10 September 2013. 
appears as being extremely incomplete since the judicial possibility to establish an environmental damage is one thing, but its effective reparation is another - and the first is incomplete without the second.

These two frameworks, European and American, give examples of what can be accomplished to reach a better coordination of the jurisdictions in a perspective that would further aim at the environmental protection. For that reason, the analysis will be more rigorous. Two problems must be analyzed regarding the liability of the companies for environmental damages: the existence of rules applicable to the relationship between the courts and claimants or defendants from other States, (I) and the possibility of making the parent-companies liable for the damages caused by the subsidiary companies established in foreign countries (II).

\section{Rules applicable to the relationship between the national courts and claimants or defendants from other States}

In the United States, there are provisions in the judicial system to start proceedings against the American multinationals responsible for damages in foreign countries (1). As far as the European Union system is concerned, it does not include any means regarding this. (2).

\subsection{The Aliens Tort Act: a judicial system for the victims of the subsidiaries established in foreign countries}

The Alien's Tort Claims Act is a tool of universal jurisdiction ${ }^{16}$ which enables American courts to judge the damages committed by public agents or private American entities abroad. This action contributes to the debate on the denial of justice that unfolds in this context, although the discussions rather deal with human rights. However, what emerges is the need to analyze this tool and its significance in the context of environmental damage.

The ATCA was adopted in 1789 to allow for the universal jurisdiction of the United States' tribunals as regards to the civil redress in the event of an infringement of an international norm which it ratified ${ }^{17}$.

16 For an opinion against the universal competence of the instrument see: WATT, H. M. L'Alien Tort Statute devant la Cour Suprême des Etats-Unis: territorialité, diplomatie judiciaire, ou économie politique ? Revue critique de droit international privé, p. 595, juil. 2013.

$17 \int 1350$. Alien's Action for Tort - the District Courts shall
It is a civil jurisdiction, explicitly, a procedure that can be settled resulting in the granting of compensations to the victims by the authors of the damages. This law does not create any substantial right ${ }^{18}$.

The norm remained unused for a long time before being reactived in 1980 in the Filartiga c. Pena-Irala ${ }^{19}$ case. In the latter case, a Paraguayan doctor, Joel Filartiga, whose son had been tortured to death by the police of his country, used this law to file a lawsuit with his daughter against one of the individuals behind these atrocities $^{20}$. Other cases in connection with the human rights ${ }^{21}$ have been brought to the United States' courts after this one. In 1995, in order to judge the chief of the Serbian war, Radovan Karadzic ${ }^{22}$, the Supreme Court has considered that the ATCA applies to the public agents but also to the private agents. In the "Unocal" case ${ }^{23}$, a different interpretation considered that applying the ATCA to a company should occur if the complicity of the American company in State action had been proved $^{24}$. In this case, the Californian

have original jurisdiction of any civil action by an alien for a tort only, committed in violation of the law of nations or a treaty of the United States». Available at: <http://www.law.cornell.edu/uscode/ html/uscode28/usc_sec_28_00001350----000-.html>. Accessed on: 21 mar. 2010. See: MUIR-WATT, H. Comparer l'efficience des droits? In: LEGRAND, P. Comparer les droits, résolument. Paris: PUF, 2009. p. 433-457; NORBERG, N. Entreprises multinationales et lois extra-territoriales: l'interaction entre le droit américain et le droit international. Revue de science criminelle, p. 739, 2005.

18 In the Sarei c. Rio Tinto case and in the Sosa case, the Supreme Court affirmed that the ATCA is « a jurisdictional statute that does not create a cause of action and has noted the availability of exhaustion in an "appropriate case." Sarei c. Rio Tinto, PLC 16449 2008, p. 16460.

19 Court of Appeals, Second Circuit, Filartiga c. Pena-Irala, 30 July 1980. Available at:<http://www.icrc.org/ihlnat.nsf/6740 8a74a589868841256497002b02e4/27721c1b47e7ca90c1256d18002 a2565!OpenDocumen>. Accessed on March, 21, 2011.

20 WILLIAN, B. Face aux crimes du marche: quelles armes juridiques pour les citoyens? Paris: La decouverte, 2010. p. 36.

21 Concerning the ATS application in the context of human rights see: HADL, G. In: Re South African Apartheid Litigation and Beyond: Corporate Liability for Aiding and Abetting under the Alien Tort Statue. German Yearbook of International Law, v. 53, 2010.

22 Court of Appeals, Second Circuit, Kadic v. Karadzic, 70 F.3d 232, 64 USLW 2231. Available at: <http://www.uniset.ca/other/ cs5/70F3d232.html >. Accessed on: 21 mar. 2011.

23 Available at: <http://www.elaw.org/system/files/Unocal. case.pdf $>$. Accessed on: 21 mar. 2011. About this topic see: SCHUTTER, O. Les affaires Total et Unocal : complicité et extraterritorialité dans l'imposition aux entreprises d'obligations en matière de droits de l'homme. AFDI, v. 52, 2006.

24 Para. 17, p. 39 «Viewing the evidence in the light most favorable to Plaintiffs, we conclude that there are genuine issues of material fact whether Unocal's conduct met the actus reus and mens 
Court of Appeal has established that the responsibility of the American companies apply to the same terms in the United States and outside the national territory ${ }^{25}$. In April 2013, in the Kiobel v Royal Dutch Petroleum Co. case, the Supreme Court decided that the ATCA was only applicable in the case where there is a sufficient link between the case in point and the United States this was not recorded in the case in point ${ }^{26}$. There are opinions asserting that the Kiobel decision questions the universal impact of the ATCA by declaring the Judge of the forum incompetent due to the foreign origin of the facts ${ }^{27}$.

Regarding the questions related to environmental damages, there were less results as regards to the liability of the companies. The cases Sarei c Rio Tinto $^{28}$ and Texaco show the power that the forum non conveniens ${ }^{29}$ still holds within the American framework to dismiss

rea requirements for liability under the ATCA for aiding and abetting murder and rape. Accordingly, we reverse the District Court's grant of Unocal's motion for summary judgment on Plaintiffs' murder and rape claims under the ATCA. By contrast, the record does not contain sufficient evidence to support Plaintiffs' claims of torture. We therefore affirm the District Court's grant of Unocal's motion for summary judgment on Plaintiffs' torture claims ». Available at: $<$ http://www.elaw.org/system/files/Unocal.case.pdf >. Accessed on: 21 mar. 2011.

25 Page 20, para 3. Available at: <http://www.elaw.org/system/ files/Unocal.case.pdf $>$. Accessed on: 21 mar. 2011.

26 Kiobel v. Royal Dutch Petroleum Co., 621 F.3d 111 (2d Cir. 2010). Available at: <http://ccrjustice.org/ourcases/current-cases/ kiobel>. Accessed on: 10 oct. 2013. About the topic see: ENGLE, Eric. Kiobel v. Royal Dutch Petroleum Co.: Corporate Liability under the Alien Torts Statute. Houston journal of international law, v. 34, n. 3, p. 499-517, 2012; DETTA, Jeffrey A. Van. Some Legal Considerations For E.U.-Based MNEs Contemplating High-Risk Foreign Direct Investments in the Energy Sector After Kobel v. Royal Dutch Petroleum and Chevron Corporation v. Naranjo. South Carolina Journal of International Law \& Business, Spring, 9, 161, 2013.

27 WATT, H. M. L'Alien Tort Statute devant la Cour Suprême des Etats-Unis : territorialité, diplomatie judiciaire, ou économie politique ? Revue critique de droit international privé, p. 595, juil. 2013.

28 Rio Tinto was sued in many cases. In each case different legal problems were discussed. 9th Circuit, Sarei c. Rio Tinto, PLC, 456 F.3d 1069, 2006. Available at: <http://www.ca9.uscourts. gov/datastore/opinions/2006/08/07/0256256.pdf >. Accessed on: 5 Apr. 2011. United-States, 9th Circuit, Sarei c. Rio Tinto, PLC, 2007, 12 April 2007. Available at: <http://www.ca9.uscourts. gov/datastore/opinions/2007/04/11/0256256.pdf $>$. Accessed on: 5 apr. 2011. United-States, 9th Circuit, Sarei c. Rio Tinto, 550 F. 3d 822, 2008. Available at: <http://www.ca9.uscourts.gov/ datastore/opinions/2008/12/16/0256256.pdf>. Accessed on: 5 apr. 2011.

29 Regarding this theory, the tribunal is able to accept or to deny its jurisdictional competence due to the fact that it is not the most appropriate tribunal to judge the case. the competence of the American judge in the judgment of the cases initiated by the foreign victims.

Rio Tinto is part of an Australian mining group which operated in the mines based in Southern Pacific islands. According to the plaintiffs, since 1972's, Rio Tinto has moved villages, caused damages to the tropical rainforest, to the rivers and was responsible for air pollution ${ }^{30}$. In 1990, a civil war broke out in Bougainville $^{31}$. During the war, the mine was been sabotaged by the population and, was closed as a result. The government used the military force to try to protect the mine. In March of 2002, the parliament formalized a peace agreement and the civil war ended.

In November 2000, the plaintiffs applied to the District Court for the Northern District of California, to request, among other things, the compensation for the damages that implicated the life, the health and the environment ${ }^{32}$. According to the victims, the environmental damage was the result of the building and the exploitation of the mine. The district court considered that the case was inadmissible, because it dealt with political questions ${ }^{33}$. As for the environmental damages, the court considered that they were not intended for the ATCA, because they were not part of a universal law recognized by all the nations, and in particular, by the Montego Bay Convention on the law of the sea ${ }^{34}$.

The Court of Appeal confirmed and invalidated a few interpretations of the first instance ${ }^{35}$. Regarding the environmental damages, the court confirmed that they could not be taken into account within the framework of the ATCA since the rights put forward were not

30 9th Circuit, Sarei c. Rio Tinto. PLC, 456 F.3d 1069, 2006.
31 9th Circuit, Sarei c. Rio Tinto. PLC, 456 F.3d 1069, 2006. p.
4126.
32 9th Circuit, Sarei c. Rio Tinto, PLC, 456 F.3d 1069, 2006, p. 4127, «The plaintiffs filed suit in federal district court seeking compensatory, punitive and exemplary damages, as well as equitable and injunctive relief on environmental contamination and medical monitoring claims, and attorney's fees and costs. They also seek disgorgement of all profits earned from the mine».

33 9th Circuit, Sarei c. Rio Tinto, PLC, 456 F.3d 1069, 2006.

34 9th Circuit, Sarei c. Rio Tinto, PLC, 456 F.3d 1069, 2006, para. 16 , «Further, assuming that UNCLOS reflects customary international law norms actionable under the ATCA, it is not yet clear whether "the international community recognizes the norm $[\mathrm{s}]$ as one [s] from which no derogation is permitted." Without more, we cannot conclude that the UNCLOS norms are also jus cogens norms

35 9th Circuit, Sarei c. Rio Tinto, PLC, 456 F.3d 1069, 2006, Conclusion. 
recognized by all the nations ${ }^{36}$. On the other hand, it refused the District court position which stated that the UNCLOS convention could not be used within the framework of the ATCA. According to the court, this convention could be considered as an agreement protected by the procedure of the ATCA ${ }^{37}$.

The defenders argued that the plaintiff must use all the possible measures in the State where the damage occurred. Regarding this argument, the decision promoted the idea that the plaintiffs did not need to use all the judicial possibilities that exist in PapuaNew-Guinea, since measures contrary to the victims interests could result from national norms and from a less satisfactory and incomplete jurisprudence ${ }^{38}$.

This decision shows the reluctance to consider the environmental damages caused overseas as admissible in the United-States. Considering that, normally, several environmental conventions are not ratified by the United States, there is a barrier to the possibility that they be considered as a right for all the nations. The Court of Appeal claimed that the unique treaty that could be protected by the ATCA procedure was the UNCLOS, which is tantamount to disregarding more than 300 treaties that have been ratified by several States. It is important to point out that the existence of the treaty has been at least envisioned, which shows the possibility to use public international law as an argument for the State's legal commitment, if such a treaty has been ratified. Here, the argument dealing with the necessity to use all the possible measures in the State where the damage has occurred prior to filing a lawsuit before the tribunals of another State

$36 \quad$ Para. 16.

37 PLC 4125, «[...] We also vacate for reconsideration the district court's dismissal of the plaintiffs' United Nations Convention on the Law of the Sea (UNCLOS) claim under the act of state doctrine, and its dismissal of the racial discrimination and UNCLOS claims under the international comity doctrine. [...] The Court found that the plaintiffs had stated cognizable ATCA claims for racial discrimination, crimes against humanity and violations of the laws of war, but that of the environmental claims, only the violation of the United Nations Convention on the Law of the Sea- UNCLOS was cognizable under the ATCA ».

38 9th Circuit, Sarei c. Rio Tinto, 550 F.3d 822, 2008. Disponible sur: <http://www.ca9.uscourts.gov/datastore/ opinions/2008/12/16/0256256.pdf>. Consulté le 5 avr. 2011, «In fact, it may well be one of the least appropriate cases in which to do so. Because, given their fears of retaliation, it is clear that plaintiffs would not need to exhaust their remedies in Papua New Guinea even under the TVPA, this is not an "appropriate case" to determine whether we should apply an exhaustion analysis in ATS cases ». has not been retained. The decision has declined the competence of the American courts to judge the case.

Another case illustrates the use of the doctrine of forum non conveniens by the American courts: the Aguinda case. In 1967, the Texaco Petroleum company, subsidiary of Texaco Inc, started to exploit oil in Equator, forming a consortium with the national company Petroecuador. Until 1990, year when the contract ended, Texaco, erected a huge oil pipeline that crossed the Amazonian forest. At the same time, it spilled tons of toxic products and wastes in the Amazon Forest, without providing any control over the environmental pollution ${ }^{39}$. In November 1993, the victims applied to the New York court accusing the oil company Texaco. According to the inhabitants of the affected Amazonian region, Texaco used methods that had been abandoned or forbidden in other countries due to their negative impacts on the environment ${ }^{40}$. In May 2003, the Court of Appeal of the second district confirmed the decision of the New York court and claimed that the forum non conveniens was applicable to the case linked to the ATCA ${ }^{41}$. The case was transferred to the Ecuadorian justice.

On October 21, 2003, the trial started before the superior court of justice of the city of Nueva Loja ${ }^{42}$, near the Colombian border. This trial, which for the first time, involved an American company in a case of pollution in a foreign country, was estimated to 6 billion in damages. The superior court of Nueva Loja emphasized the difficulty to judge the multinational companies that are protected by the legal system $^{43}$.

39 WILliAN, B. Face aux crimes du marché: quelles armes juridiques pour les citoyens?, Paris, La découverte, 2010. p. 43.

40 WILliAN, B. Face aux crimes du marché: quelles armes juridiques pour les citoyens? Paris: La découverte, 2010. p. 44.

41 Court of Appeals, Second Circuit, Maria Aguinda et autres c. TEXACO, INC.,2000, 303 F.3d 470, 11 March 2002, Decision rendered on the $16^{\text {th }}$ August 2002, p. 3, para. 9. Availabl at: $\quad<$ http://law.justia.com/cases/federal/appellate-courts/ F3/303/470/505740/>. Accessed on: 18 apr. 2011.

42 Colombie, Provincial Court of Sucumbios, Nueva Loja, María Aguinda et al., c. Company Chevron Corporation, 14 feb. 2011, case no. 2003-0002. Available at $:<$ http://chevrontoxico.com/ assets/docs/2011-02-14-judgment-Aguinda-v-ChevronTexaco. pdf.>. Accessed on: 5th apr. 2011. Also available at: < http://www. business-humanrights.org/media/documents/decision-chevrontexaco-en-ecuador-14-febrero-2011.pdf $>$.

43 Page 19 of the decision: «Por eso se va afianzando la doctrina que permite que los jueces puedan rasgar el velo de la persona jurídica y adoptar medidas respecto de los hombres y de las relaciones encubiertes tras él, de manera que se limiten los beneficios otorgados por el ordenámiento jurídico, pensados para favorecer el 
According to the decision, the level of dependence between the subsidiary and the parent-company is the factor that could demonstrate whether the first company was only a smokescreen for the second. The criteria used in the case is the following one: if the capital of the subsidiary is insufficient for the costs of the project, if there are constant authorizations to transfer funds to support the investments, then, there is a clue showing that the control of the activities was exercised by the parent-company ${ }^{44}$. However, a problem remains: obtaining the execution of the decision made by the Ecuadorian judge in the United States. And to do so, the American judge must accept that a decision adopted by a judge from another State may have judicial impacts on the American territory; this is far from being achieved ${ }^{45}$.

In the analyzed cases, the ATCA appears as a limited tool considering the interpretations given within the environmental damages framework. The Rio Tinto case added yet another criteria to analyze the judgments pronounced in the United States: the obligation of the plaintiff to use the measures available in the State where the damage occurred. Even if this criteria has not been accepted, the possibility that such an interpretation would erect further obstacles regarding the jurisdiction of the forum State in the United states still remains. But from a different perspective, the American context is even more opened than the European framework.

\subsection{The absence of a judicial tool within the European Union framework}

When a multinational is - through a subsidiary - at the origin of a pollution in a State outside the European Union, there is no provision dealing with the possibility of the victims of this third-party State to fill a claim for damages in Europe against the parent company. Within this context, where the competence to receive cases from foreign victims is very restricted, or almost absent, it is useful to analyze the rules of European competence intended for that matter.

desarrollo económico general, no solo de empresarios honestos, sino de toda sociedad; sin embargo, abusando de la división o separación patrimonial y de responsabilidad se ha utilizado el velo societario para fines perversos, que no guardan relación con su objeto". Available at: <http://chevrontoxico.com/assets/docs/2011-02-14-judgmentAguinda-v-ChevronTexaco.pdf.>. Accessed on: 29 apr. 2011.

44 Page 20 of the decision.

45 WILLIAN, B. Face aux crimes du marché: quelles armes juridiques pour les citoyens? Paris: La découverte, 2010. p. 45.
The European Union has gone through a process of standardization of the rules on conflict of jurisdictions, that consequently became a backdrop for the study of the way the coordination of several jurisdictional competences has been established. The development of the criteria has been realized on the foundation of the Brussels Convention which was used as a basis for the Regulation 44/2000, as well as that of the Lugano Convention $^{46}$. Even if a specific rule dealing with the environment has not been provided for, the existence of rules related to the competence to judge the noncontractual obligations already supplies measures enabling a coordination - which is useful in a context of environmental damage.

Within the framework of the Brussels Convention ${ }^{47}$, the specific rule, as regards to non-contractual damages, establishes that the court of the causal event is competent to judge the case ${ }^{48}$. This special rule had given rise to doubts on the proliferation of competent courts - which could only harm the uniformity in the decisions ${ }^{49}$. However, the effect of this competition between courts has been considered positive as far as an equilibrium could be created between the plaintiffs and the defenders ${ }^{50}$. The Lugano Convention of 1988 has not made any change to that rule.

The Regulation 44/2000 may be seen as making provisions for an exorbitant competence ${ }^{51}$ since it considers everything existing outside the European Union. The provisions of article 2 of the regulation 44 gives competence to the European courts to judge all those who are domiciled on their territory, whatever

46 Lugano Convention on jurisdiction and the enforcement of judgments in civil and commercial matters, 16 September 1988. Available at $:<\mathrm{http}: / /$ curia.europa.eu/common/recdoc/ convention/fr/c-textes/lug-idx.htm $>$. Accessed on the 17th September 2013.

47 About the history of the Brussels Convention see: GAUDEMET-TALLON, H. Compétence et exécution des jugements en Europe: règlement 44/2001, Conventions de Bruxelles (1968) et de Lugano (1988 et 2007). 4. éd. Paris: LGDJ, 2010. p. 3-13.

48 CJCE, Bier c/Mines de potasse d'Alsace, C-21/76, November 30, 1976, JDI, 1977, p. 728, obs. A Huet; Rev. crit. Dip, 1977, p. 563, note P. Bourel.

49 HALPERN, J. Exorbitant Jurisdiction" and the Brussels Convention: Toward a theory of restraint. In: REISMAN, W. M. (Ed.), Jurisdiction in international law, Ashgate, Aldershot, p. 487, 1999. 50 HALPERN, J. Exorbitant Jurisdiction" and the Brussels Convention: Toward a theory of restraint. In: REISMAN, W. M. (Ed.). Jurisdiction in international law, Ashgate, Aldershot, p. 488, 1999.

51 See: HALPERN (J.). Exorbitant Jurisdiction" and the Brussels Convention: Toward a theory of restraint. In: REISMAN, W. M. (Ed.). Jurisdiction in international law, Ashgate, Aldershot, p. 490, 1999. 
their nationality. When a defendant has no domicile on the territory of the European State, the competence belongs to each member State, and is settled by the law of this State according to article 4.1 of the regulation. Accordingly, the damages that occurred outside the European Union are not concerned; this does not associate third-party States to the harmonization of the rules, nor does it allow the suing of the subsidiaries of the European companies established in these States within the European framework.

In this context, the domicile of the plaintiff has no importance within the framework of the settlement: the courts of the member States of the European Union are competent even if the plaintiff is domiciled in a thirdparty State ${ }^{52}$. This restrains a better judicial cooperation with the other countries ${ }^{53}$. Even if this rule is based on the rules of the national States, which represents the policy chosen by the integration ${ }^{54}$, this provision cannot bring any valuable solution in terms of judicial protection of the environment ${ }^{55}$. The way this restriction inflicted to the third-party States can influence the reparation of the environmental damages must be, consequently, analyzed.

These rules of European competence seem to have another consequence as far as the environmental protection is concerned: to enable that the European multinationals are not sued within the European framework. This must be analyzed in the American and in the European context.

\subsection{The possibility to judge the liability of the parent companies regarding the environmental damages caused by the subsidiaries established overseas}

In the United States, it is possible to envision the liability of the parent companies regarding the

52 Unless it is a rule of exclusive jurisdiction or a jurisdictional clause See: CJUE, Group Josi Reinsurance Company Sa c. Universal General Insurance Comapany (UGIC), C-412/98, 13 july 2000.

53 MUIR-WATT, H. Conclusion. In: VAREILLESSOMMIÈRES, P. (Éd.). Forum shopping in the European Judicial Area, Oxford, p. 149, 2007.

54 See the Opinion of the Court 1/03 of 7 February 2006 on the Competence of the Community to conclude the new Lugano Convention on jurisdiction and the recognition and enforcement of judgments in civil and commercial matters. See also: NIBOYET, M. L. LA PRADELLE, G.G. Droit international privé. 2. ed. Paris: LGDJ, 2009. p. 358-359.

55 Articles 14 and 15 of the French Civil Code; article 23 of the German Civil Procedure code. See: HALPERN, J. Exorbitant Jurisdiction" and the Brussels Convention: Toward a theory of restraint. In: REISMAN, W. M. (Ed.). Jurisdiction in international law, Ashgate, Aldershot, p. 481, 1999. environmental damages caused by the subsidiaries established overseas, even if this is achieved with limits, whereas within the framework of the European Union, these limits are even more evident.

\section{The United States and the possibility to judge the liability of the parent companies for environmental damages committed overseas by the subsidiaries}

In the United States, the competence to judge the cases brought by foreigners against the American parent-companies is provided by law, but has a limited impact. When it comes to environmental damages, the retained criteria to accept a request made by foreign victims are examined by the judges who can declare the forum non conveniens. In accordance with this theory, the court can declare its judicial competence on the grounds that it is or not an appropriate court to judge this case. The different solutions provided by the cases Bhopa ${ }^{56}$, Aguinda $^{57}$, Amoco Cadir ${ }^{58}$ highlight the importance of the interpretations given to the competence of the forum State, here the United States. An analysis of the definition of the forum non conveniens in the United States must be followed by a study of the criteria's application and their implementation within the environmental damages framework.

The forum non conveniens is a theory allowing a court to dismiss a case when another court might be more appropriate for the judgment. The nature of this theory is procedural and the court has the sole discretion to accept or not a procedure in the forum State ${ }^{59}$. According to an author, this point is not, per

56 Court of Appeals, Second Circuit, Bhopal, 809 F. 2d 195, 204, 24 Nov. 1986, decision of the 14 January 1987. Available at: <http://openjurist.org/809/f2d/195/united-states-court-ofappeals-second-circuit>. Accessed on: 16 Feb. 2011.

57 District Court for the Southern District of New York, Maria Aguinda c.Texaco, 1996, 2001. Available at: <http://www. texaco.com/sitelets/ecuador/docs/aquinda_v_texaco_oao2.pdf $>$. Accessed on: 5th apr. 2011.

58 Court of Appeals for the Seventh Circuit, Amoco Cadiz, 954 F.2d 1279, 24 January 1992, decision of the 12 June 1991. Available at: <http://law.justia.com/cases/federal/appellatecourts/F2/954/1279/128596/>. Accessed on the 02 March 2011.

59 United-States Supreme Court, Gulf Oil Corp. v. Gilbert, 330 U.S. 501, 18 Dec. 1946, decision of the 10 March 1947: Wisely, it has not been attempted to catalogue the circumstances which will justify or require either grant or denial of remedy. The doctrine leaves much to the discretion of the court to which plaintiff resorts, and experience has not shown a judicial tendency to renounce one's own jurisdiction so strong as to result in many abuses. Available at: $<$ http://supreme.justia.com/us/330/501/case.html>. Accessed on 
se, in contradiction with the idea of legal certainty, considering that the basis on which this discretion will be exercised is clear for the parties ${ }^{60}$. It is a rule of law regarding a preexisting competence. The aim of this rule is to facilitate the administration of justice for every specific case, since the courts are supposed to analyze all the factual and contextual aspects of the case. On the other hand, it is possible to note, that the lack of use of precise criteria when it comes to judging environmental damages represents a legal uncertainty ${ }^{61}$.

It can also be stressed that postponing the case due to the forum non conveniens of the forum State must remain exceptional. The principle adopted is that of a presumption in favor of the forum State chosen by the claimant, unless the defendant gives the proof of the inappropriate nature of the forum State ${ }^{62}$. The admissibility of the forum non conveniens within the internal context of the United States was stated in the case International Shoe Co. v. Washington ${ }^{63}$. In order for the defendant to be better protected from an abuse of the claimant who could sue his adversary in the forum State far from his domicile, the former is always considered as the weakest. It is for that reason that the Supreme Court ${ }^{64}$ has admitted the forum non conveniens in

the 17th Sep. 2011.

60 MAYER, P. Forum non conveniens et application uniforme des règles de competence. In: VAREILLES-SOMMIÈRES, P. (Éd). Forum shopping in the European Judicial Area, Oxford, p. 138, 2007.

61 For an analysis of forum non conveniens see: USUNIER, L. La régulation de la compétence juridictionnelle en droit international privé, Paris: Economica, 2008. p. 381-386.

62 United-States Supreme Court, Gulf Oil Corp. v. Gilbert, 330 U.S. 501, 18 Dec. 1946, decision of the 10 March1947, p. 508. United-States Supreme Court, Piper Aircraft Co. v. Reyno, 454 U.S. 235, 8 Dec. 198. Available at: <http://supreme.justia.com/us/454/235/>. Accessed on: 23 nov. 2011. For an opposite decision see: Court of Appeals, Second Circuit, Bhopal, 809 F. 2d 195, 204, 24 nov. 1986, decision of the 14 Jan. 1987. See: MASSÉNAT (V.M.), Les conflits de procédures et de décisions en droit international privé, Paris: L.G.D.J, 2007. p. 196.

63 United-States Supreme Court, International Shoe CO. $c$. Washington, 326 U.S. 310, 3 Dec. 1945, «Historically the jurisdiction of courts to render judgment in personam is grounded on their de facto power over the defendant's person. Hence his presence within the territorial jurisdiction of court was prerequisite to its rendition of a judgment personally binding him. Pennoyer v. Neff, 95 U.S. 714 , 733. But now that the capias ad respondendum has given way to personal service of summons or other form of notice, due process requires only that in order to subject a defendant to a judgment in personam, if he be not present within the territory of the forum, he have certain minimum contacts with it such that the maintenance of the suit does not offend 'traditional notions of fair play and substantial justice». Available at: < http:// caselaw.lp.findlaw.com/cgi-bin/getcase. pl?court $=U S \& v o l=326 \&$ invol=310 $>$. Accessed on the 15 Feb. 2011.
American law, which enables the determined tribunal to decline the exercise of its competence, if it appears as particularly inappropriate for the defenders ${ }^{65}$. In addition, we should study the way the courts determine which tribunals will be the more appropriate to judge the case, and which criteria can be derived from this analysis ${ }^{66}$.

Concerning the environmental damages, the principal cases Bhopal and Aguinda show that the concept of the forum non conveniens has been used by the American judges to dismiss their competence on claims for compensation for the environmental damages. The concept seems to have been employed in an exceptional and reasonable way, since the criteria used to justify the competence of the foreign court towards the American court have not been justified. On the

U.S. 501, 18 Dec. 1946, decision of the $10^{\text {th }}$ March 1947, p. 507, «The principle of forum non conveniens is simply that a court may resist imposition upon its jurisdiction even when jurisdiction is authorized by the letter of a general venue statute. These statutes are drawn with a necessary generality, and usually give a plaintiff a choice of courts, so that he may be quite sure of some place in which to pursue his remedy. But the open door may admit those who seek not simply justice, but perhaps justice blended with some harassment. A plaintiff sometimes is under temptation to resort to a strategy of forcing the trial at a most inconvenient place for an adversary, even at some inconvenience to himself ». Available at: <http://supreme. justia.com/us/330/501/case.html>. Accessed on: 16 Feb. 2011.

65 MASSÉNAT, V. M. Les conflits de procédures et de décisions en droit international privé, Paris: L.G.D.J, 2007. p. 195.

66 See: United-States Supreme Court Gulf Oil Corp. v. Gilbert, p. 508 et 509, «Important considerations are the relative ease of access to sources of proof; availability of compulsory process for attendance of unwilling, and the cost of obtaining attendance of willing, witnesses; possibility of view of premises, if view would be appropriate to the action, and all other practical problems that make trial of a case easy, expeditious, and inexpensive. There may also be questions as to the enforceability of a judgment if one is obtained. The court will weigh relative advantages and obstacles to fair trial. It is often said that the plaintiff may not, by choice of an inconvenient forum, "vex," "harass," or "oppress" the defendant by inflicting upon him expense or trouble not necessary to his own right to pursue his remedy. But, unless the balance is strongly in favor of the defendant, the plaintiff's choice of forum should rarely be disturbed. Factors of public interest also have place in applying the doctrine. Administrative difficulties follow for courts when litigation is piled up in congested centers instead of being handled at its origin. Jury duty is a burden that ought not to be imposed upon the people of a community which has no relation to the litigation. In cases which touch the affairs of many persons, there is reason for holding the trial in their view and reach, rather than in remote parts of the country where they can learn of it by report only. There is a local interest in having localized controversies decided at home. There is an appropriateness, too, in having the trial of a diversity case in a forum that is at home with the state law that must govern the case, rather than having a court in some other forum untangle problems in conflict of laws, and in law foreign to itself $»$. 
other hand, in the Amoco Cadiz case, the competence to judge a damage that occurred in France has been accepted by the American courts. The difference in the latter case is that the arguments of the French victims have been rather substantial, whilst in the first cases, the arguments were strongly based on the procedure, so that it was important to analyze how the American courts adopt reasonable decisions on their competence when faced to the jurisdiction of the other courts.

The accident of Bhopal occurred on December 3, 1984. It was caused by poisonous gases produced by the factory of the Union Carbide India Limited (UCIL) located in Bhopal, India ${ }^{67}$. Several people died and many still suffer the physical consequences of this pollution. The Indian government published the Bhopal act to formalize its competence to represent the victims of the damage. The American courts were chosen by the victims but declared that they were incompetent to judge a case that occurred in another State, the latter having more connections with the event.

The victims claimed that the Indian forum could not be competent since the Indian system was not capable of judging such a complex case, as the delays of the procedure were too long $^{68}$. The laws in India appeared as being inefficient since there are no codifications in tort law, neither in class action ${ }^{69}$.A decision of the Indian forum could not be executed in an appropriate form in the United States ${ }^{70}$. As for the private interests claimed by the defendant, it is possible to mention the following arguments: the principal proofs were in India ${ }^{71}$; the persons who were working in Bhopal were in India; the persons who controlled the company were in India ${ }^{72}$.

The final decision ${ }^{73}$ rendered in 1987, has confirmed the 1986 judgment of the First Instance tribunal. It has considered that the forum tribunal was competent to judge since: a) the Indian system has material and procedural resources for a legal decision to be

67 See: <http://www.bhopal.com/incident-response-andsettlement>. Accessed on: 26 apr. 2011.

68 Bhopal, page 12 of the decision.

69 Bhopal, page 17 and 20 of the decision.

70 Bhopal, page 22 of the decision.

71 Bhopal, page 25 of the decision.

72 Bhopal, page 27 of the decision.

73 Court of Appeals, Second Circuit, Bhopal, 809 F. 2d 195, 204, the $24^{\text {th }}$ Nov. 1986, decision of the 14th Jan. 1987. Available at: <http://openjurist.org/809/f2d/195/united-states-court-ofappeals-second-circuit>. Accessed on the 16 fév. 2011. adopted $^{74}$; b) the principal activities of the company were developed in India. Regarding the question of the public interests of India and the United States, the decision was adopted in favor of an interpretation according to which India had approved the activities of the company ${ }^{75}$. The decision has, moreover, claimed that the interest of India, which was to create contingency and protective standards for the citizens, was stronger than the interest of the United States to control the exportations of the American companies in connection with their production of potentially pollutant technologies. Besides, the Indian State had granted tax benefits to incite the companies to invest in India. In that case, the American court considered that judging this case would go beyond its competences and, as a result, the interest of India was stronger than that of the United States. ${ }^{76}$

After that decision, another case was brought before Indian courts in 1987, the Mebta c. Union of India case ${ }^{77}$. In this judgment, the theory of piercing the social veil, which is part of the Indian jurisprudence, was applied. The responsibility of the parent-company has been admitted due to the statement of the existence of a real control over the subsidiary, which had based its activities in Bhopal. The control of the executive and of the management of the Indian subsidiary has been subject to extensive analysis considering that they were holding $50,9 \%$ of the actions. However, the execution of the decision was difficult, because the victims have not managed to obtain any compensation from the parent-company. From this judgment, an agreement was adopted which only compensates $15 \%$ of the

74 Bhopal, page 23 of the decision.

75 Bhopal, page 52 of the decision.

76 Bhopal, page 57 of the decision, «The Indian interest in creating standards of care, enforcing them or even extending them, and of protecting its citizens from ill-use is significantly stronger than the local interest in deterring multinationals from exporting allegedly dangerous technology. The supposed "blackmail" effect of dismissal by which plaintiffs are troubled is not a significant interest of the American population, either. Surely, there will be no relaxing of regulatory standards by the responsible legislators of the United States as a response to lower standards abroad. Other concerns that bald fear of potential liability such as convenience or tax benefits, bear on decisions regarding where to locate a plant. Moreover, the purported public interest of seizing this chance to create new law is no real interest at all. This Court would exceed its authority were it to rule otherwise when restraint was in order $»$.

77 Supreme Court of Índia, M.C. Mebta and Anrc. Union Of India \& Ors, AIR, SC 965, 1086, 20 Dec 1987. Available at: <http://www.indiankanoon.org/doc/1486949/>. Accessed on the 23rd Nov. 2011. 
damages, that represented an amount of 470 millions of dollars. This example points out the challenge that faces the execution of this decision when the company that must pay compensation for the damage is located in a State that has not judged the case - the United States in this specific case.

Other actions have been initiated in the United States, in particular in 1989, in Texas, in order to obtain reparation ${ }^{78}$. The victims contested that the Indian government was their representative in accordance with the Bhopal Act which gave the government the power to represent the victims ${ }^{79}$. The First Instance Tribunal and the Court of Appeal decided that the American courts were not competent to judge decisions made by the Indian government ${ }^{80}$. Moreover, several civil and criminal suits followed, but without many results for the victims $^{81}$. Only a decision of 2008 Sabu c. Union Carbide ${ }^{82}$ has considered that the victims could not have access to American procedures ${ }^{83}$, which is not tantamount to an acceptation of the substantial arguments.

78 Court of Appeals, Second Circuit, 984 F.2d 582 , 61 USLW 2457, decision of the $26^{\text {th }}$ Jan. 1993.

79 Court of Appeals, Second Circuit, 984 F.2d 582 , 61 USLW 2457 , decision of the $26^{\text {th }}$ Jan. 1993, para. 8, «India passed the Bhopal Act to "secure that claims arising out of, or connected with, the Bhopal gas leak disaster are dealt with speedily, effectively, equitably and to the best advantage of the claimants." Preamble to Bhopal Act. To effectuate the swift and just resolution of claims, section 3 of the Act delegates to the Indian Government "the exclusive right to, represent, and act in place of (whether within or outside India) every person who has made, or is entitled to make, a claim for all purposes connected with such claim in the same manner and to the same effect as such person».

80 Court of Appeals, Second Circuit, 984 F.2d 582 , 61 USLW 2457 , decision of the $26^{\text {th }}$ Jan. 1993, para. 13, " Any challenge appellants may have to the settlement must be made through the legislative or judicial channels that are available in India. We hold that when a recognized democracy determines that the interests of the victims of a mass tort that occurred within its borders will be best served if the foreign government exclusively represents the victims in courts around the world, we will not pass judgment on that determination, and we will permit only the foreign government access to our courts to litigate those claims, subject of course to our own requirements for standing. This conclusion is especially compelling in a case such as this where almost all of the victims are Indian citizens».

81 See: <http://www.earthrights.org/legal/sahu-v-union-carbide>. Accessed on: 26 $6^{\text {th }}$ apr. 2011.

82 Court of Appeals, Second Circuit, Sahu c. Union Carbide Manhattan, 06-5694.

83 Court of Appeals, Second Circuit, Sabu c. Union Carbide Manhattan, 06-5694, "A three-judge panel of the New York City-based 2nd U.S. Circuit Court of Appeals found that a federal trial court in Manhattan should have given the
Indeed, the American tribunals' competence to judge the reparation of damages is not recognized, even after several attempts from the Indian government and the victims of damages.

In a similar sense, the Aguinda case ${ }^{84}$ also demonstrates the reluctance of the American courts to judge the damages committed by the American multinationals. Thus, a subsidiary of the oil company Texaco, has been responsible for environmental damages due to oil exploitation with a lack of waste management - since 1964. In November 1993, the Ecuadorians, started two class actions against the parentcompany Texaco in the Southern District of New York ${ }^{85}$. In 1994, the Peruvians also started a class action against Texaco before the same court ${ }^{86}$. The two plaintiffs complained that between 1964 and 1992, the activities of Texaco had polluted the forests and the rivers in Equator and Peru. Their principal argument was that the operations of Texaco had been designed, controlled, conceptualized and directed from the United States ${ }^{87}$. The plaintiffs were asking reparation for the damages based on the theories such as due diligence, the public and private nuisance, the strict responsibility and the violation of the ATCA. Moreover, they were asking

plaintiffs more opportunity for discovery rather than granting the defendants' summary judgment motion. In addition to Union Carbide, the defendants in the 2004 litigation include Warren Anderson, a former chief executive officer for the company. The 2004 litigation reportedly was filed after a 1999 case making similar allegations was dismissed». Available at: $<$ http://www.abajournal.com/news/article/us_appeals_court_ oks_suit_over_alleged_union_carbide_water_pollution_india $/>$. Accessed on the $26^{\text {th }}$ April 2011.

84 District Court for the Southern District of New York, Maria Aguinda c.Texaco. 1996, 2001, p. 1, para 1. Available at: <http://www. texaco.com/sitelets/ecuador/docs/aquinda_v_texaco_oao2.pdf $>$. Accessed on: 5th apr. 2011.

85 District Court for the Southern District of New York, Maria Aguinda c.Texaco. 1996, 2001, p. 1, para 1. Available at: <http://www. texaco.com/sitelets/ecuador/docs/aquinda_v_texaco_oao2.pdf $>$. Accessed on: 5th apr. 2011.

86 See: Court of Appeals, Second Circuit, Jota c. Texaco, Inc.,nos.97-9102, 97-9104, 97-9108, decision of the $5^{\text {th }}$ Oct. 1998. Available at: <http://caselaw.findlaw.com/us-2nd-circuit/1281761. html $>$. Accessed on: $17^{\text {th }}$ sept. 2011. United-States, Court of Appeals, Second Circuit, Jota c. Texaco, Inc.,nos.97-9102, 97-9104, 97-9108, decision of the $5^{\text {th }}$ Oct. 1998. Available at: <http://caselaw.findlaw. com/us-2nd-circuit/1281761.html>. Accessed on: 17th sept. 2011.

87 Court of Appeals, Second Circuit, Maria Aguinda et autres $c$. TEXACO, INC.,2000, 303 F.3d 470, 11 March 2002, decision of the $16^{\text {th }}$ Aug. 2002, para. 2. Available at: <http://law.justia.com/ cases/federal/appellate-courts/F3/303/470/505740/>. Accessed on: 18 th apr. 2011. 
reparations for environmental damages, namely: cleaning the contaminated places, the creation of an access to drinkable water and the re-establishing of the conditions of fishing and hunting. The creation of a fund for the environmental protection has also been requested $^{88}$.

The plaintiffs argued that the competent forum State was the Ecuadorian forum and that the doctrine of the forum non conveniens should be applied ${ }^{89}$. They claimed that the Ecuadorian forum was the most capable of judging because the victims, the proofs and the indispensable parties for the case, like Petro-Ecuator, were in Equator, and that the judgment outside Equator would be a violation of the sovereignty of Equator ${ }^{90}$. The District Tribunal considered the arguments of the defendant and affirmed the competence of Equator to judge the case on the sole condition - which was by the way fulfilled-, that Texaco accepts to be summoned before an Ecuadorian court.

The plaintiffs appealed to ask the reconsideration of the forum non conveniens ${ }^{91}$. Their arguments were justified by private and public interests, which pointed towards the competence of the American jurisdiction. According to them, there were no sufficient proofs to back up the judgment of the parent-company in the United States $^{92}$. On May 30, 2001, the court has, on the basis of the doctrine of forum non conveniens, verified if another alternative could exist to judge this case.

The court then claimed that for the question of the more adequate forum to be settled, two degrees of

88 Court of Appeals, Second Circuit, Maria Aguinda et autres $c$. TEXACO, INC.,2000, 303 F.3d 470, du 11 March 2002, decision of the 16 Aug. 2002, p. 3, para. 2. Available at: <http://law.justia.com/ cases/federal/appellate-courts/F3/303/470/505740/>. Accessed on the 18th april 2011.

89 Court of Appeals, Second Circuit, Maria Aguinda et autres c. TEXACO, INC.,2000, 303 F.3d 470, 11 March 2002, decision of the 16 aug. 2002, p. 3, para. 9. Available at: <http://law.justia.com/ cases/federal/appellate-courts/F3/303/470/505740/>. Accessed on: 18th apr. 2011.

90 Court of Appeals, Second Circuit, Maria Aguinda et autres c. TEXACO, INC.,2000, 303 F.3d 470, 11 March 2002, decision of the $16^{\text {th }}$ Aug. 2002, p. 3, para. 9.

91 Court of Appeals, Second Circuit, Maria Aguinda et autres c. TEXACO, INC.,2000, 303 F.3d 470, p. 4, para. 12.

92 District Court for the Southern District of New York, Maria Aguinda c.Texaco, 1996, 2001, p. 2, para. 2, Nonetheless, the plaintiffs, after taking numerous depositions and obtaining responses to no fewer than 81 document requests and 143 interrogatories, were unable to adduce material competent evidence of meaningful Texaco involvement in the misconduct complained of to the point that plaintiffs essentially stipulated as much. analysis were necessary: 1) the court should analyze if another adequate forum State existed; 2) in this case, the interests and the factors linked to the private and public interests of the parties who wanted to have the case judged in a special forum should be weighed ${ }^{93}$. Whether the defendant could be sued by other courts is an element which should as well checked and established. If the Ecuadorian forum did not have procedures capable to receive a foreign defendant, then the Ecuadorian court may not be adequate ${ }^{94}$. The court judged, despite the arguments brought by the victims who were highlighting all the procedural and material deficiencies of the Ecuadorian forum, that Equator was an adequate forum in law.

The competence of the American courts to judge whether a foreign court is more competent to judge internal cases is not reasonable. There will still be a court that will be more competent to judge a concrete case. The question that is set, is to give the victim the choice of the court that could bring the best result to the concrete case. When the victims decide to go towards another court, they have motives to move to another State's jurisdiction, considering that it would be easier for them to file a claim before their court of origin. Each court should be competent to analyze its competence to judge the case that has been submitted to it ${ }^{95}$.

To better define the positive perspective related to the forum's competence in the judgment of damages that occurred in another State, it is interesting to examine the Amoco Cadiz case. The French plaintiffs preferred, here, to deal with the United States, as the latter had not

93 Court of Appeals, Second Circuit, Maria Aguinda et autres c. TEXACO, INC.,2000, 303 F.3d 470, p. 7, para. 24, «Ordinarily, the requirement of an adequate alternative forum "will be satisfied when the defendant is 'amenable to process' in the other jurisdiction. In rare circumstances, however, where the remedy offered by the other forum is clearly unsatisfactory, the other forum may not be an adequate alternative $»$.

94 Court of Appeals, Second Circuit, Maria Aguinda et autres c. TEXACO, INC.,2000, 303 F.3d 470, p. 7, para. 22, «After determining the degree of deference owed to a plaintiff's choice of forum, a district court engages in a two-step inquiry. First, the court must consider whether an adequate alternative forum exists. If so, it must "then balance a series of factors involving the private interests of the parties in maintaining the litigation in the competing fora and any public interests at stake ». See also: Court of Appeals, Second Circuit, Wiwa c. Royal Dutch Petroleum Co., 226 F.3d88, decision of the $14^{\text {th }}$ Sep. 2000. Available at: < http://law.justia.com/ cases/federal/appellate-courts/F3/226/88/540109/>. Accessed on the 23th Nov. 2011.

95 JOUBERT, N. La Notion de liens suffisants avec l'ordre juridique (Inlandsbeziebung) en droit international privé, Paris: Litec, 2008. p. 5. 
ratified the convention on the civil responsibility linked to the damages caused by pollution, which limits the responsibility of the polluter. In that case, the Second Conflicts Restatement was applied since it confers to the United States, the competence to judge a party that has committed or that is accused of having committed an act in the State where the extra-contractual damage has occurred $^{96}$.

In this case, an American company was sued in the United States for damages caused to the French victims on the French territory. The object of the dispute was an oil tanker, ordered and built in Spain, but registered in Liberia. The owner company, the Amoco Transport $\mathrm{Cy}$, was subjected to Liberian law, and was itself, a subsidiary of a chemical oil group, the Standard Oil Cy. The head office of this Indiana Company, and its activity were based in Chicago. The standard oil Cy had another subsidiary, the Amoco International oil $\mathrm{Cy}$. The latter was a company incorporated in Delaware, with its head office and principal place of activities located in Chicago Illinois. It has been in charge of the order and reception of the Amoco Cadiz. The ship was insured in Great Britain, and had an Italian captain at the time of the disaster. The Shell group was the owner of the cargo at this time ${ }^{97}$.

Beyond the obvious complexity of the case, which lasted 14 years, the American judges have considered themselves as competent. The Northern District of Illinois, division East, made a first decision in January of 1988, and ruled in favor of compensations for cleaning operations, for the cost of the purchased material, the use of the public edifices, the rehabilitation of the coast and the ports, but not for the losses of the biomass $^{98}$. The decision of January 24, 1992, emitted by the United States Court of Appeal for the Seventh District confirmed the decision of the District Court ${ }^{99}$. The responsibility of the parent-company has been justified by the contribution that Amoco had brought to the situation of the ship, since it had refused to abide to the recommendation of the manufacturer regarding

96 Restatement, para. 26 (1), 1971. See about the topic: JUENGER (F.K.), « Environmental Damage. In: MCLACHLAN, C.; NYGH, P. Transnational tort litigation : jurisdictional principles. Oxford: Clarendon Press, 1996.

97 RAULIN (A.), «L'Epopée judiciaire de l'Amoco Cadiz», JDI, 1, 1993 , p. 43.

98 KISS, A.; BEURIER, J. P. Droit international de l'environnement. 3. ed. Paris: Pedone, 2004. p. 432.

99 RAULIN, A. L'Epopée judiciaire de l'Amoco Cadiz, JDI, 1, 1993 , p. 44. the proper maintenance of the equipment of the ship. Its responsibility was established due to its neglect or its lack of attention that caused the degradation of the Amoco Cadiz ${ }^{100}$. The judge has noted this interference in the technical piloting of the ship ${ }^{101}$.

In this context, the doctrine of the forum non conveniens and the rules of the States on the specific competences in the case of pollution lead to uncertainties which do not bring any precise answers to the degradations caused by the pollutions ${ }^{102}$. The analysis on the contact points with the United states, as well as the factors that are considered, provide possibilities for the flexibility of the criteria of incorporation. On the other hand, the individual analysis leads to an uncertainty for the plaintiffs who are trying to file a lawsuit in the United States.

As it was possible to observe, the criteria used by the courts can be divided between private and public, as well as procedural and substantial. The facility to bring evidence, to interrogate the victims or to be able to execute the decision is an example of the first criteria. And the general interest which is to respect the sovereignty of the other States, or the interest of each State to adopt social and environmental standards as regards to the environment will be fundamental in the judgment of the case.

In the case related to environmental damages, the private criteria that characterize the trial and legally binding factors have a direct influence on the result of the judgment. However, the judicial system must be adapted to this administration of evidence, among other things, by the realization of witnesses' investigations - procedure to which the Romano-Germanic legal systems are not used to ${ }^{103}$.

In the analyzed cases, the forum non conveniens does not seem to have been used in an exceptional way. There

100 RAULIN, A. L'Epopée judiciaire de l'Amoco Cadiz, JDI, 1, 1993. p. 52; MUCHLINSKI, P. T. Multinational enterprises and the law. 2. ed. Oxford: Oxford University Press, 2007. p. 310-311.

101 PONTAVICE, E. D. L'apport du procès de l'Amoco-Cadiz. Droit de l'environnement marin: développements récents, Société française pour le droit de l'environnement, actes du colloque du 26 et 27 de novembre 1987 à la Faculté de droit et sciences économiques de Brest. Paris: Economica, 1988. p. 273-289.

102 JUENGER, F.K. EnvironmentalDamage. In:MCLACHLAN, C.; NYGH, P. Transnational tort litigation: jurisdictional principles. Oxford, Clarendon Press, 1996.

103 MAYER, P. Forum non conveniens et application uniforme des règles de compétence. In: VAREILLES-SOMMIÈRES, P. (Ed.). Forum shopping in the European Judicial Area. Oxford, 2007. p. 140. 
has been no presumption in favor of the victims, which should be taken into account in better proportions. The fact that the victims were relocated or had left their initial forum State to fill a lawsuit in a different forum State is made for a good reason. This relocation induced several judicial and financial difficulties, since we are dealing with judicial systems that are normally very different. This is not emphasized by the courts in their decisions. If the victims state that their initial court has no procedural and substantial tools that will enable the case to be judged properly, then, this must be presumed true.

This is what stands out from the Bhopal and Aguinda case since, even if the national courts of the victims which judged the case after the American ones had declared their competence, the decision has not been, or will not be easily executed in the United States.

It appears, in this case, that the forum non conveniens, may be a way to dismiss the competence of the judges to examine a case brought by a foreign victim. A solution would be to adopt, within a new legal framwork framework, the notion of the German law, Inlandsberiehung, instead of the forum non conveniens. The goal of this German concept is to check if the dispute has a sufficient link with the legislation of the forum State, without taking into account the competence of the other courts. The fact that the court of the forum State can verify if the foreign court is more appropriate to judge the case, creates an unreasonable barrier for the victims ${ }^{104}$.

The arguments, accepted by the United States as per the Amoco Cadiz decision, have been substantial in the sense that they have analyzed the notion of control of the parent-company over its subsidiaries. The second Restatement has been used regarding the possibility to judge the extra-contractual damages. In this case, the arguments of procedures regarding the difficulty that the national courts of the victims had to judge the cases have proved to be weak. This confirms the arguments that consider the control of the parent-company over the activities of the subsidiary. Even if the solutions in the United States do not guarantee a responsibility of the parent-companies, the European provisions are even more limited.

104 JOUBERT, N. La Notion de liens suffisants avec l'ordre juridique (Inlandsbeziehung) en droit international privé, Paris: Litec, 2008. p. 5.
4 The limits of the liability of the parent-companies for damages caused outside the European Union

The European norms are limited regarding the liability of the European parent-companies for the pollution outside the European Union. The European forum may be the more appropriate to judge the case since the execution may be more efficient in the forum of the parent-company. The analysis of the provisions of the regulation of the home office of the legal person must be done by observing if the European courts could be competent to judge the parent-companies, regarding the damages caused by the subsidiaries which would be controlled within the European Union framework.

The article 60 of the regulation number 44 provides for a material rule regarding the home office of the legal person. The rule gives the applicant the choice of domicile of the corporation, either its registered office or central administration or principal place of business. The article 22 stipulates:

\section{[...] In terms of validity, nullity or the dissolution of companies or legal persons having their seat in the territory of a Member State, or validity of decisions of their organs, the courts of that Member State. To determine the head office's seat, the court shall apply its rules of private international law."}

When it comes to an environmental damage, a company may likely be asked the reparation of damage. In the case where the subsidiary of a European company would have committed damage in Brazil, it would be considered Brazilian. But if a link of direction, of control between the two companies can be proved, it could be considered as domiciled in France, for example. Notwithstanding, this interpretation has not been envisaged yet.

However, the need to consider this subsidiary as controlled by the parent-company would not be necessary if common rules existed on the capacity of the defendants of third party States to fill a lawsuit in the EU. Proposals exist on the possibility, especially within the «green book» framework of the commission concerning the revision of the Brussels Regulation ${ }^{105}$. One of them concerns "the extension of the rules of competence stated in the settlement of the disputes

105 Commission's Green Paper on the review of the Brussels I Regulation, $\operatorname{COM}(2010) 748$ final 2010/0383 (COD), Bruxelles, 14 Dec. 2010. Available at: <http://www.europarl.europa.eu/ meetdocs/2009_2014/documents/com/com_com(2010)0748_/ com_com(2010)0748_fr.pdf>. Accessed on: 12 $2^{\text {th }}$ sep. 2013. 
involving defendants from third-party countries including the case where a same action is pending in or outside the Union" ${ }^{\prime 106}$.

This context shows a few specifics provisions $\left.{ }^{107}: 1\right)$ it is expected that non-EU defendant may be sued where he has personal property, provided that the value of the property is not disproportionate to that of the debt and that the dispute has a sufficient connection with the Member State of the court seized; 2) the jurisdictions of a State Member would be able to recognize a dispute when the latter has a sufficient link with this State Member and when no other instance guaranteeing the right to an equitable trial is available (jurisdiction by necessity $)^{108}$.

But, as these changes have not occurred yet, it is important to note what are the arguments used by the State Members of the European Union to assess the liability of the parent-companies, of the subsidiaries, and the branches in particular. The possibility to extend to a subsidiary the given interpretation regarding the branches has been developed in a few cases in application of article 55 of the regulatory framework. The Somafer decision ${ }^{109}$ in particular, has interpreted the notion of branch subsidiary. According to the CJUE, the branch subsidiary can be determined by:

[...] the commitments taken by the center of the operations in the name of the parent-company, and that must be executed in the contracting State where the center of the operations is established, as well as the disputes in connection with the non-contractual obligations that would find their origin into the activities that the subsidiary branch, agency or any other establishment [...] has taken on to the place where it is established on behalf of the parent-company. ${ }^{110,}$

In this context, the cases examine contracts between the secondary establishment and third parties, as well as criminal or quasi-criminal obligations which could

\footnotetext{
106 Ibidem, p. 5.

107 Ibidem, p. 8.

108 LAHLOU, Y. ; MATOUSEKOVA, M. Chronique de droit international privé appliqué aux affaires, RDAI/IBLJ, n. 5, 2009.
}

109 CJUE, Somafer SA contre Saar-Ferngas AG, C 33/78, 22 novembre 1978. Available at: <http://eur-lex. europa.eu/LexUriServ/LexUriServ.do?uri=CELEX:619 78J0033:FR:HTML>. Accessed on: 11th feb. 2011.

110 Somafer SA contre Saar-Ferngas AG, C - 33/78, para. 13. bind the secondary establishment. The plaintiff can fill a lawsuit against a subsidiary based on their place of residence.

An autonomous interpretation of the idea of subsidiary can be found in the judgment $S_{\text {chotte }}{ }^{111}$. The court has indicated that the article 55 can eventually be applied to a secondary establishment which has a legal personality if it is characterized by a submission to the direction and control of the principal establishment and if it appears as a "decentralized extension" of the latter ${ }^{112}$. The case concerned a dispute opposing a German company, SAR Schotte GmbH, to a French company, Parfums Rothschild SARL ${ }^{113}$. The German company should have delivered perfumery items to the second company. The French company had complained that the products were defective. Yet, the deliveries of the products had been made to the company Rothschild $\mathrm{GmbH}$, whose head office is based in Düsseldor $\mathrm{f}^{114}$. Schotte had assigned Rothschild $\mathrm{GmbH}$ before the Court of First Instance in Germany. For its part, Rothschild $\mathrm{GmbH}$ argued that the debtor was actually Rothschild SARL. Afterwards, with the acceptance of the German court Schotte sued the French company ${ }^{115}$.

The company Parfums Rothschild SARL has maintained that the German jurisdiction was not competent. On the other hand, according to article 5.5, Schotte argued that a defendant could be sued into a contracting state other than the one of their domicile. Rothschild GmbH should be considered « a branch » of Parfums Rothschild SARL in the sense of this provision.

The German Court has declared itself incompetent, considering that Rothschild $\mathrm{GmbH}$ could not be considered as an agency of the establishment, as it was a subsidiary. After a prejudicial question asked to the court of appeal regarding this question, the CJUE has extended the application of this provision to a subsidiary having a legal personality. The conditions retained were that the subsidiary had the same name and had the same common direction and that besides,

111 CJUE, SAR Schotte GmbH v Parfums Rothschild SARL, C-218/86, 9 déc. 1987. Available at: <http://eur-lex.europa.eu/ LexUriServ/LexUriServ.do?uri=CELEX:61986J0218:EN:HT ML>. Accessed on: 17th sep. 2011.

112 CJUE, C-218/86, 9 Dec. 1987, paragraphs 15, 16 et 17.

113 CJUE, C-218/86, 9 Dec. 1987, para. 2.

114 CJUE, C-218/86, 9 Dec. 1987, para. 3.

115 CJCE, C-218/86, 9 Dec. 1987, para. 4. 
the businesses were conducted on behalf of the parentcompany ${ }^{116}$.

It is unfortunate that these interpretations are not extended to third countries. There is not even a solution provided for in the regulation. Some possibilities considered by other systems, as in the American system regarding the admissibility of actions brought by foreign companies, corroborate that interpretations are more favorable to requests from third countries.

\section{Conclusion}

Regarding the liability of the multinational companies for the environmental damages caused by their subsidiary, it can be noted that the tools present in the context of the rules of competence in the United States are more opened to third-party States than in the European Union. On the other hand, despite being more opened, the American tools are still very limited to be able to contribute to the efficient reparation of the environmental damages. On this basis, it is important to reflect on the necessity of a better formulation of the criteria to limit the application of the theories like the forum non conveniens and on the importance of treating the matter within the international framework.

The lack of criteria allowing the analysis of the forum non conveniens by the American courts allows decisions on the competence adopted by American courts to be grounded on the existence of other competent courts. As it has already been stated, this argument is not reasonable given that the criteria used to identify which court is more appropriate to judge the case vary according to whom compares them. It would be reasonable, for instance, to assume that the victims have chosen the court that would be the more appropriate

116 CJCE, C-218/86, 9 Dec. 1987, para.13, « II convient d'observer que la question posée vise le cas où deux sociétés portent le même nom et disposent d'une direction commune et où l'une d'entre elles, tout en n'étant pas une succursale ou une agence dépourvue d'autonomie vis-à-vis de l'autre, conclut néanmoins des affaires pour le compte de l'autre, et agit ainsi en tant que son prolongement dans les relations commerciales». to judge the case. If the victim claims and proves that their court of origin has neither tools of procedure, nor substantial tools able to judge the case properly, this fact must be assumed as being true. This point can be observed in the case Bhopal and the case Aguinda, where the judges have considered that the most appropriate forum was the one where the damage took place. This was done in accordance with the forum non conveniens principle. The displacement of the victims has not even been considered worthy.

Besides, the coordination of the international judicial competence can reduce the possibility of a conflict between the jurisdictions that would be potentially competent to settle a dispute. Regarding the environmental damages, several factors can contribute to the efficient settlement of disputes and damage reparations by the forum: the place where the evidence can be found, the assets of the defendants or the procedures that can guarantee conservative measures, among other things. Two measures can be envisaged for the judicial competence to be coordinated: a regional or international standardization or a harmonization between the competence of the various courts, or the provision at national level, of rules that could be able to settle the disputes. In the first case, the States Members of the European Union have standardized the rules of conflicts of jurisdiction, whilst the national provisions have been implemented in the United States.

To depend on the national legislation and on the interpretations of every judge can lead to injustices, as it had been seen in the context of the environmental damages caused by the American subsidiaries. It is for that reason that the provision of the rules on the conflicts of jurisdiction should be international. An eventual international convention could provide for the grounds of jurisdiction in cases related to environmental damages matter. This exists, as it has been stated in the introduction, but not in a critical way - considering the substantial results that the rule could bring in favor of a reparation of the international environmental damages. 


\section{References}

BALLARINO. Questions de droit international privé et dommages catastrophiques, R.C.A.D.I., 1990.

BATIFFOL, H. Aspects philosophiques du droit international privé. Paris: Dalloz, 2002.

BATIFFOL, H.; LAGARDE, P. Droit international privé, 7. éd. Paris: L.G.D.J., 1983. t. 2.

BUREAU, D.; MUIR-WATT, H. Droit international privé to: parte générale. Paris: PUF, 2010. t. 1.

CARON, D. D.; LEBEN, C. (Éd.), Les aspects internationaux des catastrophes naturelles et industrielles. The Hague, Martinus Nijhoff Publishers, 2001.

DET'TA, Jeffrey A. Van. Some Legal Considerations For E.U.-Based MNEs Contemplating High-Risk Foreign Direct Investments in the Energy Sector After Kobel v. Royal Dutch Petroleum and Chevron Corporation v. Naranjo. South Carolina Journal of International Law \& Business, Spring, 9, 161, 2013.

ENGLE, Eric. Kiobel v. Royal Dutch Petroleum Co.: Corporate Liability under the Alien Torts Statute. Houston journal of international law, v. 34, n. 3, p. 499-517, 2012

GAUDEMET-TALLON, H. Compétence et exécution des jugements en Europe: règlement 44/2001, Conventions de Bruxelles (1968) et de Lugano (1988 et 2007). 4. éd. Paris: LGDJ, 2010.

HADL, G. In: Re South African Apartheid Litigation and Beyond: Corporate Liability for Aiding and Abetting under the Alien Tort Statue. German Yearbook of International Law, v. 53, 2010.

HALPERN, J. Exorbitant Jurisdiction" and the Brussels Convention: Toward a theory of restraint. In: REISMAN, W. M. (Ed.), Jurisdiction in international law, Ashgate, Aldershot, p. 487, 1999.

JOUBERT, N. La Notion de liens suffisants avec l'ordre juridique (Inlandsbeziebung) en droit international privé, Paris: Litec, 2008.

JUENGER (F.K.), "Environmental Damage". In: MCLACHLAN, C.; NYGH, P. Transnational tort litigation: jurisdictional principles. Oxford: Clarendon Press, 1996.

KISS, A.; BEURIER, J. P. Droit international de l'environnement. 3. ed. Paris: Pedone, 2004. p. 432.

LAHLOU, Y. ; MATOUSEKOVA, M. Chronique de droit international privé appliqué aux affaires, RDAI/ IBLJ, n. 5, 2009.

MASSÉNAT (V.M.), Les conflits de procédures et de décisions en droit international privé, Paris: L.G.D.J, 2007.
MAYER, P. Forum non conveniens et application uniforme des règles de competence. In: VAREILLESSOMMIÈRES, P. (Éd). Forum shopping in the European Judicial Area, Oxford, p. 138, 2007.

MUCHLINSKI, P. T. Multinational enterprises and the law. 2. ed. Oxford: Oxford University Press, 2007.

MUIR-WATT, H. Comparer l'efficience des droits? In: LEGRAND, P. Comparer les droits, résolument. Paris: PUF, 2009. p. 433-457

MUIR-WATT, H. Conclusion. In: VAREILLESSOMMIÈRES, P. (Éd.). Forum shopping in the European Judicial Area, Oxford, p. 149, 2007.

MUIR-WATT, H. M. L'Alien Tort Statute devant la Cour Suprême des Etats-Unis: territorialité, diplomatie judiciaire, ou économie politique ? Revue critique de droit international privé, p. 595, juil. 2013.

NIBOYET, M. L. LA PRADELLE, G.G. Droit international privé. 2. ed. Paris: LGDJ, 2009.

NORBERG, N. Entreprises multinationales et lois extra-territoriales: l'interaction entre le droit américain et le droit international. Revue de science criminelle, p. 739, 2005.

OLIVEIRA, C. C. La réparation des dommages environnementaux en droit international: contribution à l'étude de la complémentarité entre le droit international public et le droit international privé. Saarbrücken: Universitaires Européennes, 2012.

PONTAVICE, E. D. L'apport du procès de l'AmocoCadiz. Droit de l'environnement marin: développements récents, Société française pour le droit de l'environnement, actes du colloque du 26 et 27 de novembre 1987 à la Faculté de droit et sciences économiques de Brest. Paris: Economica, 1988. p. 273-289.

RAULIN (A.), «L'Epopée judiciaire de l'Amoco Cadiz», JDI, 1, 1993, p. 43.

SCHUTTER, O. Les affaires Total et Unocal: complicité et extraterritorialité dans l'imposition aux entreprises d'obligations en matière de droits de l'homme. AFDI, v. 52, 2006.

USUNIER, L. La régulation de la compétence juridictionnelle en droit international privé, Paris: Economica, 2008.

WILLIAN, B. Face aux crimes du marche: quelles armes juridiques pour les citoyens? Paris: La decouverte, 2010.

WOLFRUM, R.; MATZ, N. Conficts in International environmental law. Berlin, 2003. 
Para publicar na Revista de Direito Internacional, acesse o endereço eletrônico www.rdi.uniceub.br ou www.brazilianjournal.org.

Observe as normas de publicação, para facilitar e agilizar o trabalho de edição. 